\title{
Hubungan Antara Lama Penggunaan Kontrasepsi Suntik Depo Medroxy Progesteron Acetate (DMPA) dengan Kadar Kolesterol Total pada Akseptor KB
}

\author{
Tri Prasetyorini', Yasyavia Hatifah Islami ${ }^{2}$, Rizana Fajrunni’mah ${ }^{3}$, Karningsih $^{4}$ \\ 1, 2, 3) Program Studi Diploma IV Teknologi Laboratorium Medik, Poltekkes Kemenkes Jakarta III \\ 4) Program Studi Kebidanan, Poltekkes Kemenkes Jakarta III \\ *Corresponding author: yasyavia08@gmail.com
}

\begin{abstract}
Background: Indonesia is the 4th country with the most population in the world. One of the government's efforts to reduce the rate of population growth is the Family Planning (KB) program. Nationally, the most widely used birth control program is contraceptive injection Depo Medroxy Progesterone Acetate (DMPA), which is more than 50\% of the total number of active family planning participants. DMPA which contains Progesterone hormone can affect fat metabolism, especially lipoprotein. The duration of the use of injected contraception for more than a year causes imbalanced estrogen and progesterone hormones which results in a decrease in HDL and an increase in LDL so that it will increases total cholesterol levels. Purposes: to determine the relationship between duration of use of Depo Medroxy Progesterone Acetate (DMPA) contraceptive injection and total cholesterol range in family planning $(\mathrm{KB})$ acceptors. Methods: this type of research is observational analytic with a sample of 35 respondents. The test used in this study was chi-square with a confidence level of 95\%. Result: showed that the $p$ value was 0.011 ( $p<0.05)$. This indicates that there is a relationship between duration of use of Depo Medroxy Progesterone Acetate (DMPA) contraceptive injection and total cholesterol range in family planning $(K B)$ acceptors. So that the longer the use of DMPA contraception, the more it increases cholesterol levels. Conclusion: there is a relationship between duration of use of DMPA contraceptive injection and total cholesterol. DMPA injection KB acceptors are expected to perform total cholesterol checks and pay attention to its levels.
\end{abstract}

Keywords: Injection KB Acceptor, Total Cholesterol, DMPA Injection Contraception

\begin{abstract}
ABSTRAK
Latar belakang: jumlah penduduk terbanyak di dunia posisi ke-4 adalah Indonesia. Upaya untuk menekan jumlah pertumbuhan penduduk yaitu dengan program Keluarga Berencana (KB). Secara nasional pengguna KB yang paling banyak adalah KB suntik Depo Medroxy Progesteron Acetate (DMPA) yaitu lebih dari 50\% dari jumlah peserta KB aktif. DMPA yang mengandung hormon Progesteron dapat mempengaruhi metabolisme lemak, khususnya lipoprotein. Lama pemakaian kontrasepsi suntik lebih dari 1 tahun akan mengakibatkan ketidak seimbangan hormon estrogen dan progesteron yang berakibat penurunan HDL dan peningkatan LDL sehingga akan meningkatkan kadar kolesterol total. Tujuan: diketahuinya hubungan antara lama penggunaan kontrasepsi suntik DMPA dengan kadar kolesterol total
\end{abstract}


pada akseptor KB DMPA. Metode: jenis penelitian yang digunakan observasional analitik cross sectional dengan jumlah sampel sebanyak 35 responden. Uji statistik yang digunakan adalah uji chi-square dengan tingkat kepercayaan 95\%. Hasil: menunjukan bahwa nilai $\mathrm{p}$ sebesar 0,011 $(\mathrm{p}<0,05)$. Hal ini berarti bahwa terdapat hubungan antara lama penggunaan kontrasepsi suntik Depo Medroxy Progesteron Acetate (DMPA) dengan kadar kolesterol total pada akseptor KB. Sehingga semakin lama penggunaan kontrasepsi DMPA maka semakin meningkatkan kadar kolesterol. Kesimpulan: terdapat hubungan antara lama penggunaan kontrasepsi suntik DMPA dengan kadar kolesterol total.

Kata kunci: Akseptor KB Suntik, Kolesterol Total, Kontrasepsi Suntik DMPA

\section{PENDAHULUAN}

Indonesia merupakan negara ke-4 dengan jumlah penduduk terbanyak di dunia. Percepatan pertumbuhan penduduk Indonesia menurut data statistik sebesar $1,49 \%$ per tahun. Usaha yang telah dilakukan pemerintah yaitu dengan Keluarga Berencana (KB). (1).

Keluarga berencana adalah suatu program dan tindakan untuk menghindari kehamilan yang tidak diinginkan, kelahiran yang sangat diinginkan, pengaturan interval kehamilan, dan dapat juga digunakan sebagai pengontrol kelahiran serta menentukan jumlah anak dalam keluarga (2). Faktor penting yang harus diperhatikan dalam upaya program keluarga berencana adalah pemilihan alat kontrasepsi yang tepat. Terdapat dua kategori pilihan metode kontrasepsi berdasarkan efektivitasnya yaitu metode kontrasepsi jangka pendek (non MKJP) seperti suntik, pil, dan kondom, metode kontrasepsi jangka panjang (MKJP) seperti Intrauterine Device (IUD), implant, Metode Operasi Wanita (MOW), dan Metode Operasi Pria (MOP) (3).

Secara nasional jumlah peserta KB aktif di Jawa Barat sebanyak 6.245.099 akseptor. Dari jumlah tersebut kontrasepsi yang digunakan antara lain: Intrauterine Device (IUD), implant, Metode Operasi Wanita (MOW), Metode Operasi Pria
(MOP), kondom, suntik, dan pil. Jumlah Peserta KB suntik sebanyak 3.335.407, peserta KB pil 1.464.126 akseptor, dan sisanya adalah jumlah akseptor KB yang lain. Dari data tersebut dapat diketahui bahwa pengguna KB suntik lebih 50\% dari jumlah peserta KB aktif yang berarti pengguna $\mathrm{KB}$ paling banyak adalah $\mathrm{KB}$ suntik (4).

Kontrasepsi suntik Depo Medroxy Progesteron Acetate (DMPA) pada umumnya lebih banyak dipilih dengan alasan mudah diperoleh dan terjangkau harganya, bidan, serta cocok untuk ibu yang menyusui. kontrasepsi DMPA biayanya relatif lebih murah dibandingkan dengan kontrasepsi lainnya. Kontrasepsi DMPA akan jauh lebih efektif apabila dilakukan dengan teratur dan sesuai dengan jadwal telah ditentukan yaitu dapat dilakukan setiap tiga bulan sekali (5).

DMPA merupakan kontrasepsi yang mengandung hormon progesterone. Hal ini dapat mempengaruhi metabolisme lemak, khususnya lipoprotein. Perubahan metabolisme lemak disebabkan adanya pengaruh hormonal sehingga mengakibatkan gangguan keseimbangan profil lemak dalam tubuh dan dyslipidemia (6). Hormon progesteron juga dapat mempengaruhi pusat pengendalian nafsu makan di hipotalamus mengakibatkan terjadinya peningkatan 
nafsu makan yang akan mempengaruhi peningkatan berat badan dan terjadi penimbunan lemak di bawah kulit (7). Penggunaan jangka panjang DMPA >12 bulan dapat menyebabkan terjadinya perubahan profil lipid (LDL, HDL, Trigliserida, Kolesterol) serum yang akan menjadi faktor resiko penyakit aterosklerosis (penumpukan lemak di dinding arteri) dan kardiovaskular (8).

Penelitian sebelumnya oleh Laila. mengenai gambaran kadar kolesterol total pada akseptor KB DMPA didapatkan nilai kolesterol total di atas nilai normal (6). Hasil penelitian yang dilakukan oleh Lestari kadar kolesterol total dan HDL pada akseptor KB DMPA lebih tinggi dibandingkan dengan pil kombinasi (9). Berdasarkan penelitian yang dilakukan oleh Dasuki, et al lama pemakaian kontrasepsi suntik lebih dari 12 bulan mengakibatkan gangguan keseimbangan hormon estrogen dan progesteron yang mengakibatkan penurunan High Density Lipoprotein (HDL) dan peningkatan Low Density Lipoprotein (LDL) sehingga berpengaruh pada kadar kolesterol total meningkat (10).

Penelitian yang dilakukan oleh Prawerti, et al tentang hubungan lama penggunaan kontrasepsi suntik 3 bulan dengan kadar kolesterol total hanya membagi 2 kategori lama penggunaan yaitu $<36$ bulan dan $>36$ bulan dan tidak membatasi minimal lama penggunaan $\mathrm{KB}$ (11). Pada penelitian tersebut juga diketahui proporsi (P) yang digunakan sebesar $25 \%$. Maka pada penelitian ini akan dibatasi dengan lama penggunaan kontrasepsi suntik DMPA yaitu $>12$ bulan, sesuai dengan penelitian sebelumnya penggunaan kontrasepsi $>12$ bulan akan menyebabkan peningkatan kadar kolesterol.
Berdasarkan uraian diatas peneliti tertarik untuk melakukan penelitian hubungan antara lama penggunaan kontrasepsi suntik Depo Medroxy Progesteron Acetate (DMPA) dengan kadar kolesterol total pada akseptor KB di Praktek Bidan Mandiri (BPM) Priyatin Am, Keb karena akseptor KB akan mendapatkan pelayanan $\mathrm{KB}$ secara langsung oleh bidan yang bertugas sehingga sangat membantu peneliti untuk mendapatkan data dan riwayat akseptor selama penggunaan KB.

\section{METODE}

Desain penelitian yang digunakan adalah observasional analitik dengan desain cross-sectional. Adapun lokasi penelitian dilakukan di Praktek Bidan Mandiri Priyatin Am,Keb Kel. Jatimurni, Kec. Pondok Melati, Bekasi pada bulan Februari - Juli 2020. Populasi pada penelitian ini adalah akseptor KB DMPA yang telah menggunakan kontrasepsi hormonal suntik selama lebih dari satu tahun dengan jumlah sampel sebanyak 35 responden. Teknik pengambilan sampel yang digunakan adalah purposive sampling. Kriteria Inklusi pada penelitian adalah wanita yang menggunakan kontrasepsi suntik DMPA lebih dari 1 tahun, akseptor KB DMPA bersedia ikut dalam penelitian dan menandatangani informed consent. Adapun kriteria eksklusi yaitu Memiliki riwayat penyakit Hiperkolesterol dengan melihat kadar kolesterol total (>200 mg/dL) sebelum menggunakan KB dan minum obat diet.

Variabel independen pada penelitian ini adalah lama penggunaan kontrasepsi DMPA pada akseptor KB dan variabel dependennya kadar kolesterol total pada akseptor KB DMPA. Definisi dan klasifikasi pada penelitian ini 1) Kolesterol 
total adalah Kadar kolesterol total yang diukur melalui pengambilan darah kapiler dengan menggunakan alat easy touch GCU. Pengkategorian kolesterol total adalah normal $(\leq 200 \mathrm{mg} / \mathrm{dl})$ dan abnormal (>200 mg/dl). Lama Penggunaan Kontrasepsi Hormonal DMPA adalah lamanya waktu responden menggunakan kontrasepsi dimulai sejak pertama kali mendapat suntikan. Kriterianya akseptor KB lebih dari satu tahun.

Pada penelitian ini bahan yang digunakan adalah darah kapiler responden yang tidak puasa diperoleh dengan cara tusukan kulit (skinpuncture) menggunakan lancet selanjutnya sampel diukur dengan alat. Analisis data menggunakan software SPSS dengan uji chi-square tingkat kepercayaan 95\%. Apabila didapatkan hasil $\alpha$ (alpha) $\mathrm{p}<0,05$ artinya Ho ditolak, sedangkan apabila $\alpha$ (alpha) $\mathrm{p}>0.05$ artinya Ho diterima.

Penelitian ini sudah mendapatkan ijin etik dari komisi etik Poltekkes Kemenkes Jakarta III dengan No.surat kaji etik KEPK-PKKJ3/175/II/2020.

HASIL

Tabel 1. Distribusi Frekuensi Usia, Pekerjaan dan Pendidikan Terakhir Responden

\begin{tabular}{lcc}
\hline $\begin{array}{c}\text { Karakteristik } \\
\text { Responden }\end{array}$ & $\begin{array}{c}\text { Frekuensi } \\
(\mathbf{n})\end{array}$ & $\begin{array}{c}\text { Persentase } \\
(\boldsymbol{\%})\end{array}$ \\
\hline Usia & & \\
$\leq 35$ tahun & 25 & 71,4 \\
$>35$ tahun & 10 & 28.6 \\
Pekerjaan & & \\
Tidak Bekerja & 31 & 88.6 \\
Bekerja & 4 & 11.4 \\
Pendidikan & & \\
Terakhir & & \\
SD & 5 & 14.3 \\
SMP & 3 & 8.6 \\
SMA & 26 & 74.3 \\
PT & 1 & 2.9 \\
\hline
\end{tabular}

Berdasarkan Tabel 1 dapat diketahui bahwa persentase usia responden yang menggunakan suntik KB DMPA lebih banyak yang berusia $\leq 35$ tahun yaitu sebanyak $71.4 \%$. Persentase pekerjaan responden sebagian besar didominasi dengan tidak bekerja yaitu sebesar 88,6\%. Pendidikan terakhir responden sebagian besar adalah SMA dengan jumlah responden sebanyak 26 orang.

Tabel 2. Distribusi Frekuensi Lama Penggunaan Kontrasepsi Suntik DMPA

\begin{tabular}{ccc}
\hline $\begin{array}{c}\text { Lama } \\
\text { penggunaan } \\
\text { (tahun) }\end{array}$ & $\begin{array}{c}\text { Frekuensi } \\
(\mathbf{n})\end{array}$ & $\begin{array}{c}\text { Persentase } \\
(\%)\end{array}$ \\
\hline $1-1.9$ & 10 & 28.6 \\
$2-2.9$ & 12 & 34.3 \\
$>3$ & 13 & 37.1 \\
\hline
\end{tabular}

Berdasarkan Tabel 2 dapat dilihat lama penggunaan kontrasepsi suntik 3 bulan DMPA pada akseptor KB paling banyak pada penggunaan > 3 tahun sebanyak 13 responden sedangkan penggunaan paling sedikit 1-1.9 tahun sebanyak 10 responden.

Tabel 3. Distribusi Frekuensi Kadar Kolesterol Responden

\begin{tabular}{ccc}
\hline $\begin{array}{c}\text { Kadar } \\
\text { Kolesterol }\end{array}$ & $\begin{array}{c}\text { Frekuensi } \\
(\mathbf{n})\end{array}$ & $\begin{array}{c}\text { Persentase } \\
(\boldsymbol{\%})\end{array}$ \\
\hline Normal & 14 & 40.0 \\
Abnormal & 21 & 60.0 \\
\hline
\end{tabular}

Berdasarkan Tabel 3 dapat dilihat bahwa kadar kolesterol total responden paling banyak pada kadar kolesterol abnormal yaitu sebanyak 21 responden $(60.0 \%)$. 
Tabel 4. Hubungan Antara Lama Penggunaan dengan Kadar Kolesterol Total pada Akseptor KB

\begin{tabular}{cccccccc}
\hline \multirow{2}{*}{$\begin{array}{c}\text { Lama } \\
\text { Penggunaan } \\
\text { DMPA } \\
\text { (tahun) }\end{array}$} & \multicolumn{4}{c}{ Kadar Kolesterol } & \multicolumn{2}{c}{ Jumlah } & \\
\cline { 2 - 6 } & $\mathbf{n}$ & $\mathbf{\%}$ & $\mathbf{n}$ & $\boldsymbol{\%}$ & $\mathbf{N}$ & $\boldsymbol{\%}$ & \\
\hline $1-1.9$ & 6 & 17.1 & 4 & 11.4 & 10 & 28.5 & \\
$2-2.9$ & 7 & 20 & 5 & 14.3 & 12 & 34.3 & \\
$>3$ & 1 & 2.9 & 12 & 34.3 & 13 & 37.1 & 0.011 \\
\hline
\end{tabular}

Berdasarkan Tabel 4 dapat dilihat bahwa responden dengan kadar kolesterol abnormal sebanyak $51,4 \%$ dari 35 responden. Sedangkan persentase terbesar adalah responden dengan kadar kolesterol abnormal pada kelompok penggunaan kontrasepsi > 3 tahun yaitu sebanyak $34,3 \%$.

Hasil analisis bivariat dengan uji Chi-Square diperoleh nilai $\mathrm{p}=0.011$ $(\mathrm{p}<0.05)$ maka Ho ditolak dan $\mathrm{Ha}$ diterima. Hal tersebut dapat diartikan bahwa terdapat hubungan antara lama penggunaan kontrasepsi suntik DMPA dengan kadar kolesterol total pada akseptor KB artinya semakin lama penggunaan kontrasepsi suntik DMPA maka semakin tinggi kadar kolesterol total.

\section{PEMBAHASAN}

Berbagai karakteristik responden dalam penelitian ini dapat dilihat dari Tabel 1 bahwa usia responden yang menggunakan kontrasepsi suntik DMPA <35 tahun lebih banyak dibandingkan dengan $>35$ tahun. Hal ini serupa ditemukan pada penelitian Roza (2017) menyatakan bahwa usia <35 tahun lebih dominan memilih kontrasepsi hormonal dibandingkan dengan non hormonal (12). Didukung juga dengan penelitian Evitasari, et al (2019) sebagian besar pengguna $\mathrm{KB}$ wanita yang masih relatif lebih muda yaitu kurang dari 30 tahun. Hal ini dikarenakan pada usia 23-35 tahun adalah fase menjarangkan kehamilan antara 2-4 tahun (13).

Tingkat pendidikan responden berdasarkan Tabel 1 pada penelitian ini sebagian besar SMA sebanyak 26 orang $(74,3 \%)$. Sejalan dengan penelitian yang dilakukan oleh Moloku, et al (2016) sebagian besar responden berpendidikan SMA dengan persentase $71,4 \%$ asumsinya pendidikan SMA adalah pendidikan yang cukup dalam hal pengetahuan dan memahami informasi tentang $\mathrm{KB}$ suntik serta efek dari pemakaian KB suntik DMPA (14). Hal ini didukung juga oleh penelitian Evitasi, et al (2019) ibu-ibu yang berpendidikan tinggi lebih terbuka menerima perubahan atau hal-hal baru guna untuk memelihara kesehatannya, termasuk efek samping penggunaan $\mathrm{KB}$ (13). Namun hal yang berbeda pada penelitian Grestasari (2014) tidak ada korelasi antara tingkat pendidikan ibu dengan pemilihan jenis kontrasepsi karena pengetahuan bisa didapatkan dimana saja baik secara formal atau nonformal.

Status pekerjaan pada penelitian berdasarkan Tabel 1 sebagian besar responden tidak bekerja atau Ibu Rumah Tangga dengan persentase $88,6 \%$. Menurut Septianingrum et al (2018) pendapatan seseorang berpengaruh dalam pemilihan kontrasepsi sebagian responden berpendapat memilih $\mathrm{KB}$ suntik DMPA dengan alasan cukup murah dan terjangkau bagi mereka. Menurut Fahrini et al dalam 
penelitian Roza dan Atzmardina (2019)

status pekerjaan pada ibu yang berpenghasilan rendah dan tidak bekerja cenderung memilih kontrasepsi dengan dukungan pelayanan $\mathrm{KB}$ gratis (12).

Berdasarkan Tabel 2 dapat dilihat lama penggunaan kontrasepsi suntik DMPA paling banyak pada kelompok penggunaan $\mathrm{KB}>3$ tahun yaitu sebanyak 13 orang $(37,1 \%)$. Menurut Prawerti, et al (2019) alasan lama pemakaian kontrasepsi suntik DMPA dalam jangka panjang disebabkan akseptor merasa sesuai dengan kebutuhannya, selain itu juga hanya cukup pergi ke fasilitas kesehatan 3 bulan sekali saja sehingga tidak perlu bolak balik (11). Serta alasan yang paling banyak responden menggunakan KB suntik DMPA karena harganya relatif murah dibandingkan dengan jenis KB lainnya.

Berdasarkan Tabel 3 dapat dilihat bahwa kadar kolesterol total responden sebagian besar dengan kategori kolesterol total abnormal yaitu sebanyak 21 responden (60.0\%). Sejalan dengan penelitian yang diteliti Dasuki et al (2008) bahwa penggunaan kontrasepsi DMPA > 1 tahun dapat meningkatkan kadar trigliserida dan LDL serta menurunkan kadar HDL (10). Hal ini disebabkan oleh hormon progesteron dan estrogen dalam tubuh tidak seimbang. Menurut Lestari et al (2019) kadar kolesterol pada kelompok DMPA lebih tinggi dibandingkan dengan KB pil (9). Hal ini disebabkan oleh hormon yang dapat meningkatkan nafsu makan dan dapat menyebabkan peningkatan berat badan. Peningkatan berat badan ini akan mempengaruhi HMGKoA reduktase yang merangsang peningkatan pembentukan kolesterol total.

Selanjutnya dapat dilihat pada Tabel 4 hubungan antara lama penggunaan kontrasepsi suntik DMPA dengan kadar kolesterol total pada akseptor KB paling banyak pada kelompok >3 tahun dengan kadar kolesterol total abnormal dengan persentase $34.3 \%$. Sesuai dengan penelitian yang dilakukan oleh Agustiyanti (2017) kontrasepsi hormonal memiliki beberapa efek antara lain hormon progesteron dapat merendahkan kadar HDL-kolesterol serta meninggikan kadar LDL-kolesterol dalam darah sehingga kadar kolesterol darah meningkat. Penelitian yang dilakukan oleh Agustiyanti ini diuji dengan Fisher's Exact Test dengan nilai $\mathrm{p}<0,05$. Didukung oleh penelitian Dilshat, et al (2016) kandungan hormon progesteron yang berlebihan pada sistem kardiovaskuler dapat menyebabkan perubahan kadar kolesterol yang merupakan bagian efek samping. Selain itu juga mengakibatkan terjadinya peningkatan kadar kolesterol dengan lama pemakaian kontrasepsi.

Dari penjelasan berbagai sumber maka menurut peneliti semakin lama penggunaan suntik KB DMPA maka kadar kolesterol pada responden semakin tinggi. Hal ini dapat tergambar pada kelompok penggunaan >3 tahun sebanyak 12 responden yang memiliki kadar kolesterol total abnormal. Meskipun penelitian ini memiliki keterbatasan yaitu sebagian besar responden tidak mengetahui riwayat kolesterol sebelumnya.

\section{KESIMPULAN}

Semakin lama menggunakan kontrasepsi suntik DMPA maka semakin tinggi kadar kolesterol totalnya.

\section{UCAPAN TERIMAKASIH}

Penulis ingin mengucapkan terima kasih kepada semua orang yang mendukung dalam proses penelitian. 


\section{KONFLIK KEPENTINGAN}

Penulis tidak memiliki konflik kepentingan, dan tidak ada afiliasi atau koneksi dengan atau dengan entitas atau organisasi apa pun, yang dapat menimbulkan pertanyaan baik dalam diskusi dan kesimpulan naskah.

\section{REFERENSI}

1. Jurisman A, Kurniati R. Hubungan Karakteristik Ibu dengan Pemilihan Kontrasepsi di Puskesmas Padang Pasir Padang. J FK Unand. 2016;5(1):191-5.

2. Pinasti A. Pengaruh Penggunaan Kontrasepsi Suntik Terhadap Peningkatan Berat Badan Dan Kenaikan Tekanan Darah Pada Akseptor Keluarga Berencana Di Puskesmas Kecamatan Sukodono Kabupaten Sragen. Universitas Muhammadiyah Surakarta; 2013.

3. Septalia R, Puspitasari N. Faktor yang Mempengaruhi Pemilihan Metode Kontrasepsi. J Biometrika dan Kependud. 2016;5(2):91-8.

4. BKKBN. Laporan Akuntabilitas Kinerja Instansi Pemerintah Tahun 2018. Jawa Barat; 2018.

5. Natalia C, Undre R, Bataha YB. Hubungan Pengetahuan dengan Kepatuhan Ibu Pengguna Kontrasepsi Suntik Depo Medroksi Progesteron Asetat (DMPA) di Wilayah Kerja Puskesmas Ranotana Weru Kec. Wanea Manado. J Keperawatan. 2014;2(2).

6. Laila D. Pemeriksaan Kadar Kolesterol Total pada pengguna $\mathrm{Kb}$ Suntik 3 bulan di Desa Ngumpul Kecamatan Jogoroto Kabupaten Jombang. Insan Cendekia Medika; 2019.

7. Sitinjak HL. Perbedaan Kadar
Trigliserida dan Indeks Massa Tubuh Antara Akseptor Pil Kombinasi dengan DMPA. J Endur. 2019;4(2):335-42.

8. Oktova R, Amir A. Perbedaan Profil Lipid pada Progesteron Asetat dengan Akseptor Implant Depo Medroksi di Levonorgestrel Wilayah Kerja Puskesmas Air Tawar Padang Tahun 2014. J FK Unand. 2015;4(1):45-52.

9. S HL, Rita RS, Yusrawati. Perbandingan Kadar Kolesterol Total Dan Hdl Antara Akseptor Kb Pil Kombinasi Dengan Dmpa. Indones J Kebidanan. 2019;3(1):110.

10. Dasuki D, Sanger O, Sudradjat FJ, Pamuji ES. Pengaruh Kontrasepsi Hormonal Planibu @ Versus Depo Progestin ${ }^{\circledR}$ Terhadap Fungsi Hepar Dan Profil Lipid Effect of Hormonal Contraception Planibu ${ }^{\circledR}$ Versus Depo Proges-. Ber Kedokt Masy. 2008;24(3):156-61.

11. Prawerti N, Runiari N, Ruspawan I. Lama Pemakaian Kontrasepsi Suntik Depo Medroksiprogesteron Asetat dengan Kadar Kolesterol pada Akseptor KB. 2019. Politeknik Kesehatan Denpasar;

12. Elvia Roza ZA. Hubungan penggunaan kontrasepsi suntik DMPA dengan peningkatan berat badan pada akseptor di Puskesmas Tapus Sumatera Barat tahun 2017. Tarumanagara Med J. 2019;2(1):37-42.

13. Evitasari M, Kholisotin, Agustin DY. Pengaruh Efek Samping Penggunaan Kontrasepsi Terhadap Kejadian Unmet Need Di Wilayah Kerja Puskesmas Klabang Kabupaten Bondowoso. Al- 
Aslamiyah Nurs J Nurs Sci.

2019;8:53-65.

14. Moloku M, Hutagaol E, Gresty H.

Hubungan Lama Pemakaian Lama

Kontrasepsi Suntik 3 Bulan Dengan

Perubahan Berat Badan di

Puskesmas Ranomuut Manado. J

Keperawatan. 2016;4(1):1-8. 